\title{
Planning for the local impacts of coal facility closure: Emerging strategies in the U.S. West
}

\section{Authors: Julia H. Haggerty, Mark N. Haggerty, Kelli Roemer, and Jackson Rose}

NOTICE: this is the author's version of a work that was accepted for publication in Resources Policy. Changes resulting from the publishing process, such as peer review, editing, corrections, structural formatting, and other quality control mechanisms may not be reflected in this document. Changes may have been made to this work since it was submitted for publication. A definitive version was subsequently published in Resources Policy, vol. 57, August 2018, DOI\# 10.1016/i.resourpol.2018.01.010.

Haggerty, Julia H. , Mark N. Haggerty, Kelli Roemer, and Jackson Rose. "Planning for the local impacts of coal facility closure: Emerging strategies in the U.S. West." Resources Policy 57 (August 2018): 69-80. DOI: 10.1016/j.resourpol.2018.01.010.

Made available through Montana State University's ScholarWorks scholarworks. montana.edu 


\title{
Planning for the local impacts of coal facility closure: Emerging strategies in the U.S. West
}

\author{
Julia H. Haggerty ${ }^{\mathrm{a}, *}$, Mark N. Haggerty ${ }^{\mathrm{b}}$, Kelli Roemer ${ }^{\mathrm{a}}$, Jackson Rose ${ }^{\mathrm{a}}$

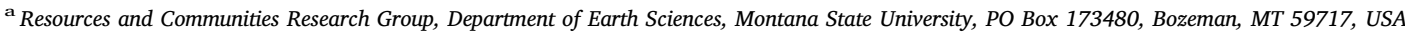 \\ ${ }^{\mathrm{b}}$ Headwaters Economics, PO Box 7059, Bozeman, MT 59771, USA
}

\begin{abstract}
A B S T R A C T
This study considers the contours of the coal transition in the United States from the perspective of local planning responses to coal plant retirements in the U.S. West. Plant closures in the region affect a diverse set of geographies and have developed in a complex, uncoordinated policy environment. The study applies an assessment framework informed by economic geography and community planning scholarship to a dataset of 12 planning documents written by and for local communities experiencing coal facility closures. The findings highlight the absence of effective strategies to address lost local revenues, lack of connections between environmental quality and long-term economic resilience, and a range of levels of acceptance of the coal transition. Together, the plans demonstrate the negative consequences of an uncoordinated, contradictory policy environment for transition planning at the local level and the need for policy interventions to address issues of equity and efficiency in this process.
\end{abstract}

\section{Introduction}

Along with many advanced economies, the United States is undergoing a major energy system transition characterized by widespread retirement of coal-fired electricity generation facilities. In less than a decade and half-between 2009 and 2025-the U.S. will retire roughly one-fifth of its coal power plant fleet (U.S. Energy Information Administration [EIA], 2017a). These developments pose immediate challenges for the localities and regions that host coal-fired power plants. For example, affected municipalities need to plan for the loss of coal employment and tax revenue while ensuring thorough decommissioning and remediation of a major industrial facility (Raimi, 2017). The fate of coal-dependent communities is an important challenge for contemporary resource policy. Though they are few, coal-dependent communities have come to symbolize the fate of the industrial economy of the U.S. in national political debates (Grunwald, 2017). In addition, successfully addressing the social, economic, and environmental legacies at coal facilities is a normative priority of policy actors and natural resource scholarship in the "just transition" arena (Newell and Mulvaney, 2013).

This paper offers a characterization and assessment of strategies that are emerging to respond to the impacts of coal power plant closures in the continental U.S. West, where approximately ten percent of U.S. coal plant closures are occurring. Encompassing 12 continental states, ${ }^{1}$ the West has a unique history in U.S. energy systems that entails having undergone massive and rapid development of new power plants and mines in the 1970s and 1980s in response to the region's post-war urbanization; national concerns about fuel scarcity and energy independence; and federal mandates for low-sulfur coal (Robertson, 1979; Hayes, 1980; Wilkinson, 1999). Home to many sovereign indigenous nations, featuring high volumes of federally-owned land and mineral resources, and marked by extreme contrasts and spatial distances between fast-growing urban areas and isolated resource hinterlands, the West poses multiple concerns and challenges in energy transitions. The study focuses on the range of approaches in existing transition plans to address the specific social, economic, and environmental context of each community. This analysis is important because community planning responses will be one among several important influences on how local places navigate the economic transition after coal plants close.

The paper's analysis of local transition planning in the region has two components. First, we situate coal plant closures in the region's economic geography to assess the nature of social and economic vulnerability to plant closure impacts. Second, we analyze existing economic transition plans developed for affected communities $(n=12)$ based on a framework that synthesizes insights from applied economics, 
community development and rural sociology literatures. The assessment framework focuses on four strategies important for economic transition in different types of communities-revenue replacement, environmental reclamation, economic development, and acceptance of transition. We deploy this framework to assess if and how the economic transition plans identify and propose goals and actions that reflect critical development strategies that are appropriate to the community's economic context. The organization of the paper is as follows: Section 2 contextualizes the economic geography of coal plant closures in the West; Section 3 provides a conceptual framework for analysis based in the literature; Section 4 shares the results of the analysis of local transition plans. A discussion of recommendations concludes the paper.

\section{Context: coal plant retirements in the U.S. West}

Between 2009 and 2017, 166 coal-fired power plants retired generators or closed entirely in the United States, reducing national coalfired power generation capacity by $16 \%$ (EIA, 2017a). Facility retirement rates and lower utilization of the remaining fleet explain the sharp decline in U.S. coal demand for electricity generation, which declined by $24 \%$ from 2010 to 2015 (from 975 to 738 million tons) (EIA, 2016, 2017b). Coal mining employment fell by a similar share (23\%) between 2008 and 2015. An additional 36 plants $(12 \%$ of the remaining coal fleet) are scheduled to retire by 2025 , further decreasing coal generating capacity by $8 \%$ (EIA, 2017a).

Both policy and market forces are influencing U.S. coal plant retirement rates. In the U.S. West, coal-fired power plants are closing due to competition from natural gas and renewable energy sources, stagnant overall electricity demand, and environmental regulations (Fleischman et al., 2013; Hourser et al., 2017). New air quality regulations were enacted in 2011 that limit mercury and other air toxics emissions from coal-fired power generators (the MATS Rule) (U.S. Environmental Protection Agency, 2016). Compliance requires expensive, pollution-control upgrades; and thus, plays a role in accelerating the timing of some plant closures, particularly for older, less efficient, and more-costly coal-fired plants (EIA, 2014). States, utilities, and consumers are also pursuing goals for cleaner, low-cost energy that put coal-fired electricity at a market disadvantage (Rabe, 2006). The recent rollback of climate policy and environmental regulations by the Trump Administration (Tollefson, 2017) is unlikely to reverse the fortunes of generating units already scheduled for retirement (U.S. DOE, 2017).

Using a combination of federal data ${ }^{2}$ and informal interviews with regional policy experts, we identified 18 coal-fired power plants that have retired since the year 2009 or have scheduled retirements at one or more generating units (41 generating units in total). Only plants with combined generating thresholds of $75 \mathrm{MW}$ or higher with owners classified as in the electric power sector or independent power producer category were included in the dataset. In many cases, retirement applies only to one of several generating units; any plant where one or more generating unit met the above criteria was included in our dataset. The 18 retiring plants have a combined generating capacity of $11.7 \mathrm{GW}$, one-third of the capacity that was operating in the West in 2000 (34.9 GW) (Map 1) (see Supplemental Material (SM) for list and details).

\subsection{Regional factors}

The physical and political geographies of the U.S. West's energy systems strongly influence dynamics of the coal transition in the region, particularly because they together imply highly complex policy and stakeholder landscapes. Coal-fired power plants in the West include

\footnotetext{
${ }^{2}$ EIA-860 Monthly Electric Generator Inventory (https://www.eia.gov/electricity/ data/eia860m/).
}

smaller facilities generating power near industrial and municipal consumers. These facilities may use coal transported by train from remote regions or local coal resources. In North Dakota, an agricultural state, lignite mines fuel small plants that contribute to the Midwestern electricity grid and local agricultural processing facilities. In addition, western states such as Arizona, Wyoming, and Montana are home to large mine-mouth facilities that export electricity to remote urban centers in other states-typical of the "coal-by-wire" model.

In the 1970s, the quest for energy independence and the demand for low-sulfur coal to address acid rain impacts in the eastern states encouraged a national energy policy focused on the rapid and extensive development of the vast coal resources of the Interior West and Northern Great Plains. National ownership of the coal resource made it possible to use federal policy to encourage rapid development of the new strip mines, railroads, mine-mouth power plants, and transmission lines in the 1970s and 1980s (Gerking and Hamilton, 2008). Federalindustry partnerships also played an important role in enabling the rapid development of a coal-based electricity infrastructure in the region. This infrastructure focused on using the resources of remote interior regions to meet the fast-growing energy needs of the region's booming metropolitan areas, located in a few interior cities (Phoenix, Denver, and Salt Lake City) and coastal hubs (Seattle, Portland, and Los Angeles).

In less than two decades, the West witnessed the build-up of a vast infrastructure that moves coal from the region's strip mines to power plants around the country via railroad; and electricity from interior coal-fired power plants to urban centers, especially on the West Coast. The result is one of the world's most spatially-extensive electricity grids; all of the U.S. West is a single electric interconnection (Map 1).

Shortly thereafter, the West was one of the leaders in the national movement to deregulate electricity markets, a disruptive event that shifted ownership and regulatory responsibility from states to market and private actors (Joskow, 2000). Subsequent energy market crises encouraged 're-regulation' in several states where deregulation had produced adverse consequences. Yet the legacy of deregulation remains, primarily in the form of a continued role for outside investors (as owners of independent power producers and investors in publicallytraded utilities) in the overall energy market of the region.

As a consequence of this history, neither the policy nor the stakeholder environment guiding transitions in the West is straightforward. Coal-fired power plant closures are occurring amongst a diverse array of ownership interests and political jurisdictions. Thirty-two unique entities have ownership in one or more of the 18 western coal plants that have retired or plan to retire generators. Among the 32 are 13 investor-owned utility companies, four independent power producers, four cooperatives, and a variety of public owners, including eight municipalities, the state of Arizona, and the Federal Bureau of Reclamation (Headwaters Economics, 2017a). A generator unit may have multiple owners, with the ownership portfolio varying across plant assets. For example, Montana's Colstrip facility has four units. Two units are owned by Talen Energy (an independent power producer (IPP)) and Puget Sound Energy (PSE, a regional investor-owned utility (IOU)). Ownership of Units 3 and 4 is divided among six entities: PacifiCorp (IOU), Avista (IOU), Portland General Electric (IOU), Talen Energy (IPP), PSE, and NorthWestern Energy (IOU) (Haggerty et al., 2017). The service territories of Colstrip's utility owners-and thus the range of stakeholders in facility planning-are diverse and include large metropolitan areas (Seattle, Washington, and Portland, Oregon) as well as rural areas of three states. An ownership base remote from the plant location is characteristic of the large coal-by-wire facilities across the West. The various types of plant owners have different incentives that come to bear on decision-making about end-of-life processes. For example, investor-owned utilities in the Western states typically work in a rate-of-return model overseen by elected or appointed state regulators, while independent power producers are more directly accountable to financial markets. Cooperatives and municipal entities operate under 


\section{Coal Electricity Infrastructure and Major Cities in the U.S. West}

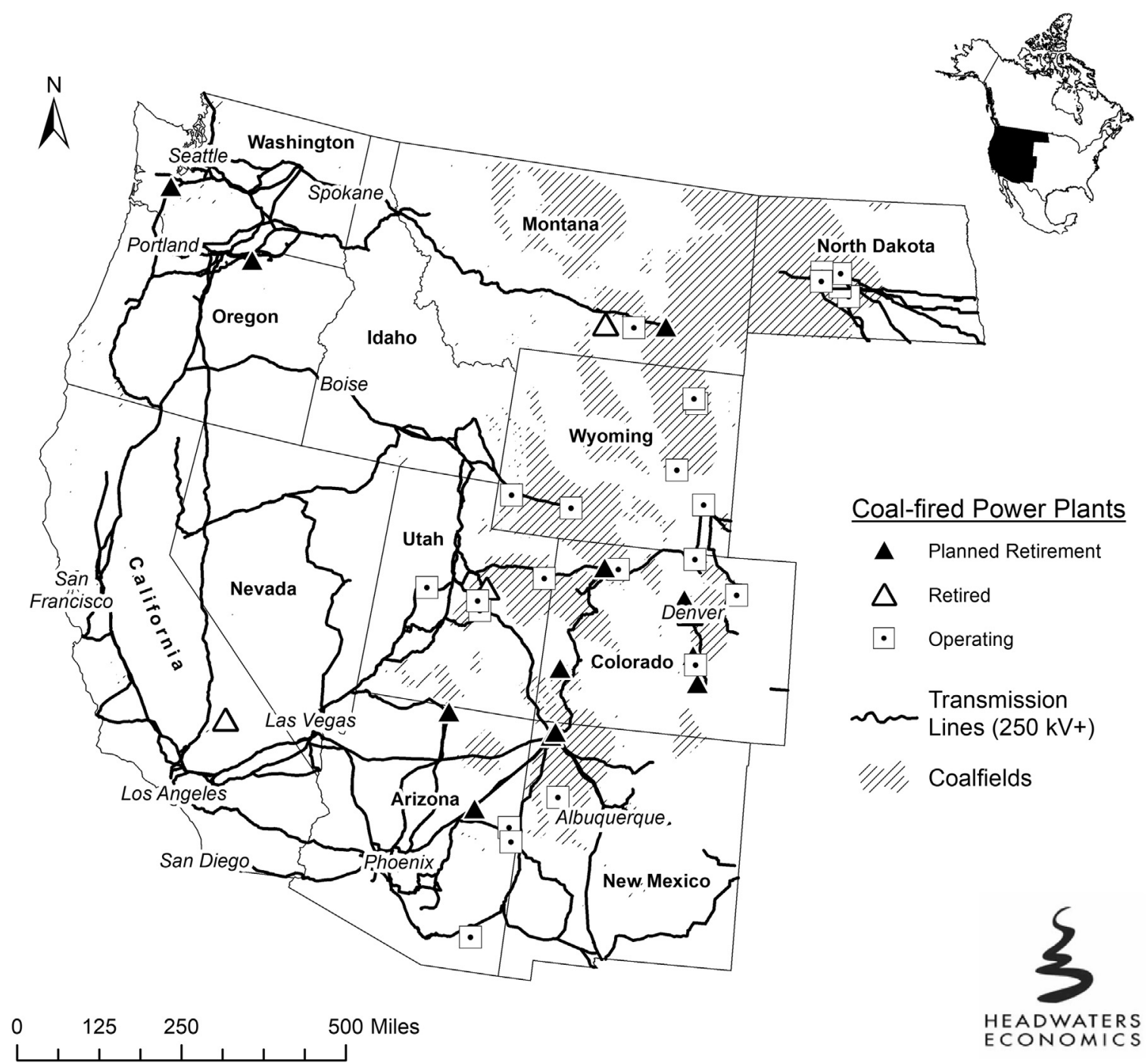

Map 1. Coal Resources and Coal Electricity Infrastructure in the U.S. West.

Source: (Authors)

similar incentives to regulated utilities but have a less diffuse stakeholder cohort.

The fragmented ownership and sprawling stakeholder geographies of coal facilities in the West complicate an already disjointed and difficult regulatory and planning environment related to closure and transition (Taylor et al., 2016; Whitener, 2005). No single policy framework guides the process for transition planning at coal-fired power plants. Multiple state and federal policies set the terms of environmental remediation and waste management while various financial regulations establish responsibilities for costs. Within this framework, individual plant owners negotiate their internal priorities for plant retirement and site decommissioning, typically focusing on limiting longterm liability and cost-efficiency (Raimi, 2017). As for local social and economic impacts, state and federal assistance or intervention occurs (if it does) on a case-by-case basis.

From the perspective of local communities facing power plant closures, opportunities to evaluate and plan for long-term impacts are not mandated features of retirement and decommissioning processes. Transition planning may or may not coincide with robust economic development processes. In the United States, the dominant framework for economic development is imposed by a federal mandate: to receive federal funding for public works or other programs, local governments and other applicants must update a Comprehensive Economic Development Strategy (CEDS) on a 5-year basis (U.S. Economic Development Administration [EDA], 2017). There is a basic template for CEDS documents, and many localities struggle to meet the recommended process of robust public engagement in the planning process due to limited capacity (EDA, 2017). The Obama Administration introduced a funded program to support coal communities with planning and investments, "POWER Plus," in 2016. At the time of writing, it is highly uncertain whether the Trump administration will continue POWER Plus program. The policy discussions show a clear shift in dominant rationale away from supporting transition toward policies intended to subsidize coal (Higdon, 2017). In this policy landscape, facility retirement and decommissioning planning in the West is highly localized, operating without established meta-governance or templates.

\subsection{The economic geography of the West's plant closures}

Coal-fired power plant closures also are playing out across a diverse economic geography in which local opportunities vary widely based on access to markets and the presence of amenities associated with the growth of the knowledge and service economies. The assets upon which economic vitality in the region now depends are largely found in the 
West's larger cities and some rural areas connected to cities via reliable air transportation (Rasker et al., 2009). In this context, rural communities isolated from cities have fewer obvious development options (Whitener, 2005).

Primary industries (such as coal facilities) often play an outsized role in the local and regional economy in isolated communities, which are likely to experience significant consequences from events like closures that would be less noticeable in a metropolitan area (Besser et al., 2008; Betz et al., 2015). The U.S. West's experience of the decline in the timber industry bears this risk assessment out (Charnley et al., 2006). In remote locations, relatively few job opportunities exist for laid-off coal workers, and it is more difficult to attract and grow other types of jobs, particularly those that rely on advanced education. These communities also face a set of challenges associated with productivity gains that limit the employment opportunities in primary industries; such as uncertain policies and government funding for rural services and continued boom and bust market dynamics (Headwaters Economics, 2017c).

To distinguish among various local contexts for coal retirements, we apply Rasker et al. (2009)'s "Three Wests" typology in which counties are metropolitan, connected, or remote as measured by mean driving time to airports. Given the vast area of the some of the counties in our study, we also describe community context in terms of the distance of the plant from major airports. Coconino County, a metropolitan county in Arizona that hosts a 2250 MW power plant on the Navajo Reservation describes the importance of this two-pronged consideration: at just under 20,000 square miles in area, the county is the second-largest county in the United States. Its metropolitan status derives from the city of Flagstaff, home to over $90 \%$ of the county's population and a major airport with daily commuter services. The power plant, by contrast, is located on the Navajo Nation's homelands, more than two hours driving time away from the regional airport and a world apart economically from Flagstaff.

The following illustrations demonstrate the diversity in economic circumstances of facilities closing in the West. A complete list of plants and their attributes is provided in the Supplemental Materials. Fig. 1 charts the volume (in GW) of recent and planned retirements by three economic geographies. On the left are those plants located in counties designated as "double isolated" based on their remote location in an isolated county. The central bar represents generation facilities in a remote location in a county that is connected or metropolitan in its overall economic geography. The bar on the right describes facilities in a central location in a connected or metropolitan county. Table 1

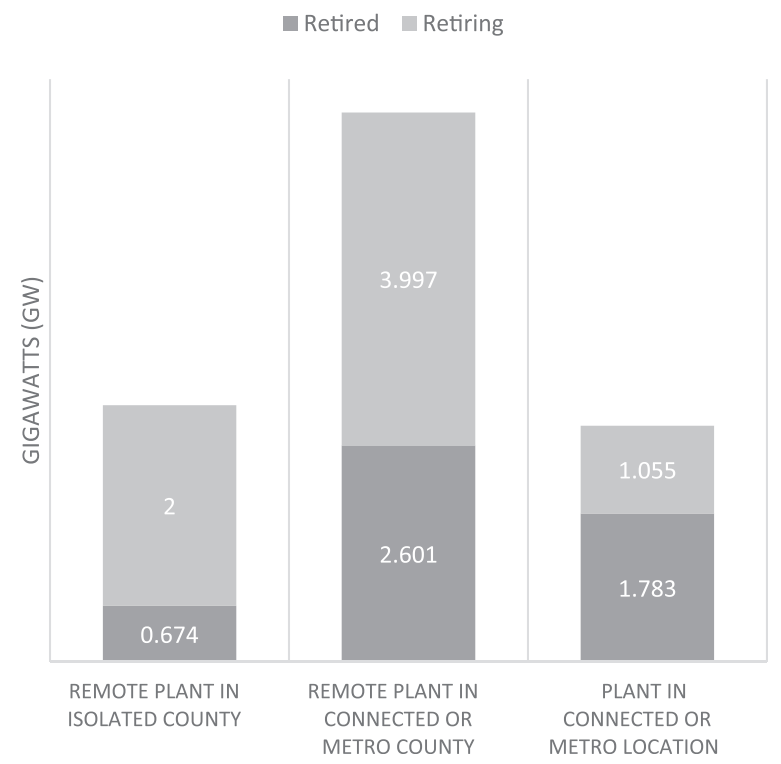

Fig. 1. Coal Generation Capacity (GW) Retired/Retiring in the West, by Geography. Source: Authors after EIA data and "Three Wests" Typology. (Rasker et al., 2009). provides basic social and economic indicators that suggest some of the major differences in the potential vulnerability of the county cohorts to the loss of a coal-fired power plant.

Each of the charts of standard economic and demographic performance indicators in Fig. 2 brings attention to the different context in isolated counties. Compared to metro counties, average wages are lower in isolated counties, there are fewer jobs in high wage services, and income volatility is greater. Fewer adults in isolated counties college degrees compared to connected and metro counties and the population is older.

Considering isolation both in terms of the county and actual site of the power plant, five of the West's retired or retiring plants feature "double isolation"-Colstrip (Rosebud County, MT), Cholla (Navajo County, AZ), Stanton (Mercer, ND), Carbon (Carbon, UT), and TransAlta (Lewis, WA). These plants are on average more than two hours driving distance from an airport with daily commercial commuter flights and are located in isolated counties. Plants located in metro and connected counties but relatively remote from a city or airport, such as the Navajo Generating Station (Coconino, AZ), may have advantages with respect to revenue strategies. While these communities will face economic development challenges consistent with an isolated location, the county's larger and more diverse tax base may provide stability relative to isolated counties. Other plants are located in metropolitan counties and relatively close to cities and airports, including the Valmont (Boulder, CO), Cherokee (Adams, CO), and Arapaho (Denver, $\mathrm{CO})$ plants on Colorado's Front Range.

\section{Effective planning for transition in coal-dependent communities}

Scholars in economic and rural geography, sociology, and related disciplines have devoted substantial attention to the drivers and outcomes of consolidation in primary industries and industrial facility closure (Freudenburg, 1992). A complementary body of work considers the general qualities that encourage resilience to shocks, such as the loss of a major employer, at the local scale (Besser et al., 2008; Kulig et al., 2013; Vaneeckhaute et al., 2017). These bodies of research emphasize several impacts and strategies related to economic transition. Four primary themes emerge and serve as the conceptual basis for this study's assessment criteria in this report: (1) the importance of replacing and stabilizing revenue streams; (2) the necessity to plan, fund, and execute complete environmental remediation; (3) the risk of focusing on economic development strategies that are inappropriate to local context; (4) the association of willingness to change and positive outlook with community resilience during transitions. Another set of community development strategies that emphasize a participatory and transparent process during closure, remediation, and transition planning (Morrison-Saunders et al., 2016) and support from state and federal entities (Hourser et al., 2017; Rosenfeld, 2015; Taylor et al., 2016) are addressed in a companion paper (in preparation). The rationale for the four thematic dimensions of effective transition planning is as follows.

\subsection{Addressing lost revenue}

Local governments in the western states provide a wide variety of public services (public safety and public works), administer state mandates (organizing elections, assessing property, and recording documents), and are increasingly engaged in providing social and health services, environmental conservation, and economic development activities (workforce development, business support, and marketing activities) (Istrate, 2014). For regions experiencing the loss of a major employer, these roles and activities of local governments are central to adapting to and succeeding in the changing economy (Halseth and Ryser, 2006; Sullivan et al., 2014).

Revenue generated by coal mining and coal burning is the largest 


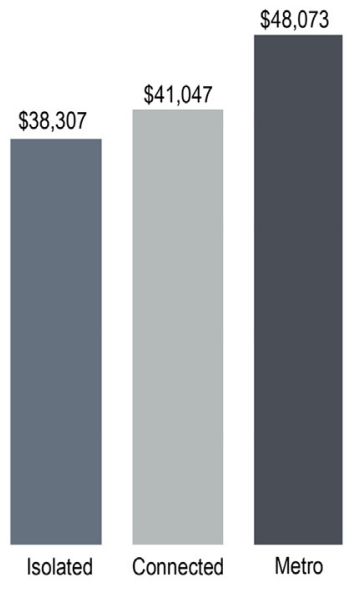

Average Earnings per Job (2013)

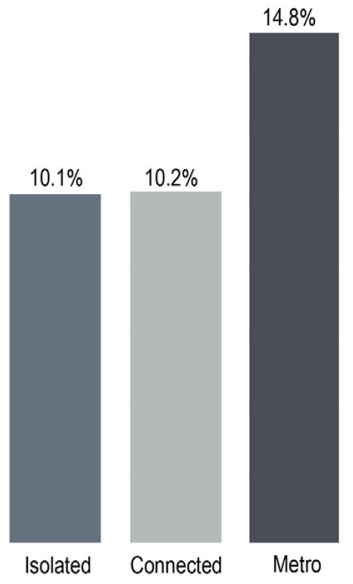

Average Jobs in High Wage Services (2013)

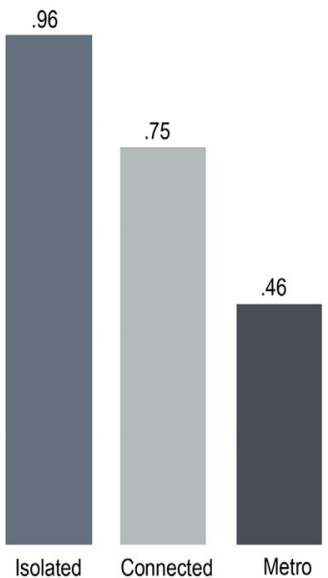

Average Income Volatility

(1970-2013)
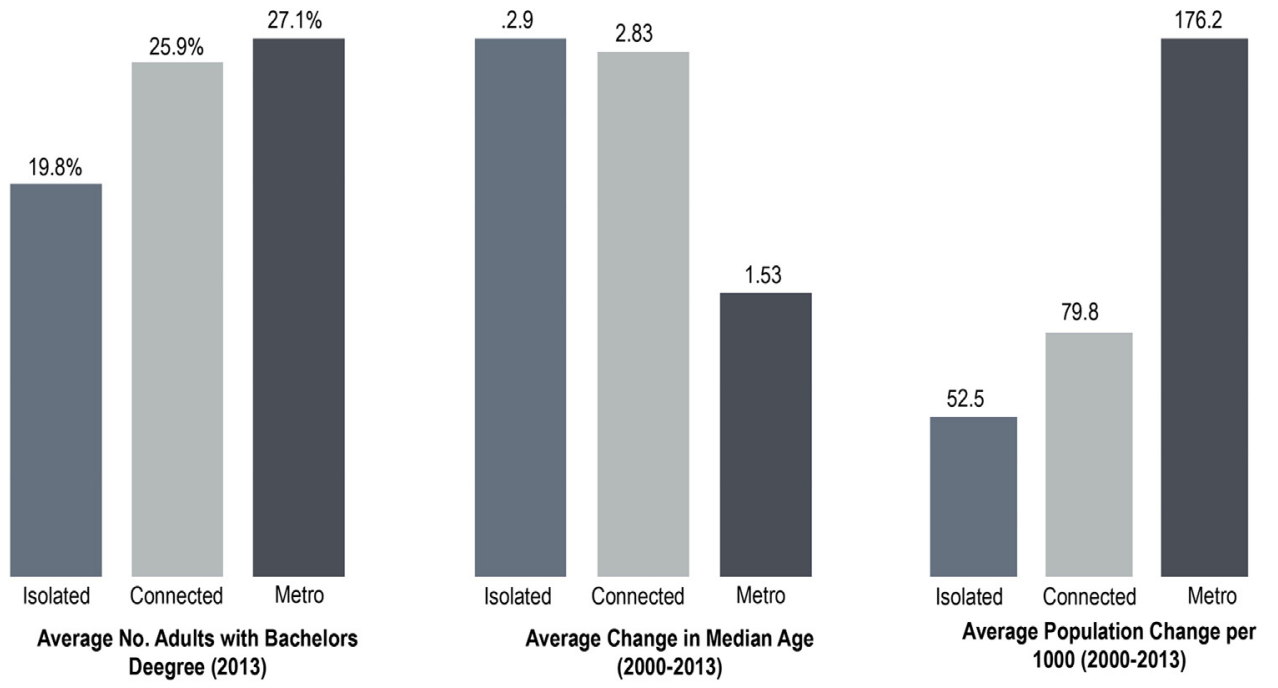

Fig. 2. Economic and demographic vulnerability indicators for county cohorts.

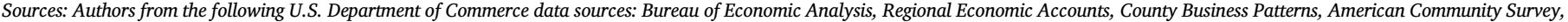
Systems Support Division.

benefit of resource extraction (Haggerty and Haggerty, 2015) and can be the single largest source of revenue for local governments (Raimi, 2017). Investing these revenues in long-term savings, infrastructure development, and economic development efforts can stabilize and diversify rural economies, creating a virtuous cycle of growth (Boettner et al., 2012; Gunton, 2003). Leveraging wealth from resource extraction into place-based investments aligns with economic development approaches for resource regions recommended by new regionalism (Markey et al., 2008), a shift from a focus on competitive advantages-largely based on resource availability-to comparative advantages that highlight a wider array of qualities (e.g., human capital, infrastructure, natural amenities, and quality of life) (Gunton, 2003; Kitson et al., 2004) and community economic development that stresses bottom-up approaches to planning that build local capacity (Ryser and Halseth, 2010).

Transition plans need to have a fiscal strategy to address the loss of revenue when a power plant closes. The loss will be experienced in different ways based on state and local tax policies. The way that power plants are valued for property tax purposes affects the total valuation while the plant is operating and the decline in valuations after it is retired and/or decommissioned (Raimi, 2017). The timing of retirement also is important. Communities where some generation capacity will continue to operate for more than five or ten years (e.g., in Colstrip, MT where two generators will continue operating to 2027 or beyond) have time to reduce dependence on coal revenue in the short term and stabilize revenue beyond plant retirement. Transition plans also should properly characterize the role of local government employment, infrastructure, services, and partnerships; and revenue strategies should be designed to ensure rural institutions critical to transition are maintained. Economic development literature tends to discourage strategies focused on a single industry or firm. Instead, supporting institutions, services, workforce, and quality of life that benefit all businesses argues for consistent and stable funding for local governments (Fan et al., 2016; Neumark and Simpson, 2015).

\subsection{Including environmental restoration in economic development}

Decommissioning, remediation, and environmental reclamation requirements and activities can provide short and long-term economic development opportunities for transitioning communities. Two different types of benefits are important. First, the activities associated with remediating environmental damage and contamination and restoring sites and landscapes involves a substantial investment. The restoration economy is a growing economic sector and employs a workforce, equipment, and capital similar to that displaced by the end of extraction and consumptive activities (BenDor et al., 2015; Hibbard and Lurie, 2013; Kelly and Bliss, 2009; Taylor et al., 2016). Strategies focused on securing adequate funding for restoration activities, utilizing 
the local workforce in restoration activities, and tying restoration goals to economic diversification strategies can maximize the economic opportunity during transition and shape a vision of desired restoration outcomes.

The second benefit of thorough remediation involves the role that environmental amenities, including scenery and access to recreational opportunities, play in rural growth (Deller et al., 2001; McGranahan, 2008; Winkler et al., 2007). Degraded environments associated with coal mining and coal burning can hamper long-term growth (Fan et al., 2016; Goetz et al., 2017). Investing in remediation meets public and environmental health imperatives and plays a role in combatting negative economic effects of legacy contamination. In addition, remediation and restoration can be substantial investments and as such, represent opportunities for local employment. Restoration strategies that go beyond site clean-up to include improvements to environmental qualities, recreation opportunities, and other amenities are fundamental to long-term economic development and transition. Strategies include: regulations during mining and coal burning operations that seek to limit future liability and costs; revenue strategies that ensure adequate resources are available for restoration after retirement and decommissioning; workforce and business development strategies that seek to utilize local skills and labor, particularly workers and businesses displaced by retirements; and robust public planning and participation in defining restoration goals and synergies with recreation, tourism, retirement, and entrepreneurial economic development strategies.

\subsection{Adopting strategies appropriate to local context}

A third key element in transition plans involves an accurate reading of recent and current economic conditions. Properly characterizing economic context and geography is critical to developing economic, fiscal, and workforce strategies that have potential for success in the local economic context.

Opportunities for transition may exist for rural communities given proper understanding and sensitivity to context. For example, rural areas with access to metropolitan markets are creating jobs in new service sectors; regions with high-amenity landscapes are attracting new residents, tourists, and retirees (Beale, 2017); and some rural communities with low energy costs have attracted small manufacturing and data centers (Aspen Institute, 2017; Headwaters Economics, 2017b). Small towns with advantages in housing affordability, safety, and quality of life are attractive to retirees, residents, and businesses who want to locate where they also have access to good schools, health care, cultural services, and infrastructure. Efforts that improve the overall quality of local institutions and workforce, and support local entrepreneurs are associated with growth even in isolated regions (Stephens et al., 2013). Resource and commodity booms can still lift rural places, and where adequate structures are in place to retain the wealth generated by these activities locally, can help stabilize and diversify rural economies. These strategies align with policy recommendations prompted by "new regionalism" that suggest the region is the most appropriate scale to advance economic development, and proposes leveraging endogenous capacities of isolated communities (MacLeod, 2001).

By comparison, strategies that seek to attract a single firm or sector (Neumark and Simpson, 2015), particularly when doing so relies on removing or weakening environmental protections or lowering taxes to compete with urban areas for jobs (effectively undermining the endogenous capacities of isolated regions). Investing in economic development activities that are inappropriate to local context also are likely to fail, for example attempting to develop a high-tech cluster in isolated communities.

Critics of the new regionalism highlight the limits and opportunities imposed on isolated regions by federal and state policy and national and global markets (MacKinnon et al., 2002). Appropriate strategies for power-plant communities must pair strategies intended to identify and develop local assets and individuals with strategies aimed at strengthening and growing linkages to outside markets, policy networks, and capital.

Communities facing industrial decline often do not successfully transition to a more diversified economy that can support a similar sized population that existed before the loss of a major employer (Smith et al., 2001). Rust belt cities in the U.S., for example, have begun planning to shrink the size of communities (Hollander et al., 2009). Similar planning efforts should be discussed and understood in isolated communities losing coal-fired power plants. A focus on workforce assistance, including workforce training, education, and relocation assistance, may be successful in assisting displaced workers but also can facilitate mobility; benefiting workers while contributing to population loss in affected community. The best strategies for workers and communities may not overlap (Renn, 2016).

\subsection{Outlook on transition}

Shifts in the broader political economy have placed a substantial burden on local capacity in responding to economic and other kinds of disruptive shocks (Woods, 2005). The case of coal transitions, especially since the 2016 presidential elections, is not much different. Studies that address determinants of community agency in response to shocks straddle the disciplines of rural sociology, community, psychology, community development and applied economics. Several decades of work on differential rural community experiences of economic restructuring as well as natural disasters document the importance of social capital to effective mobilization. Social capital's constructive role in local agency depends not only internal social cohesion including shared vision and the ability to manage conflict (bonding capital), but also on linkages to external network nodes that provide ideas, resources and support to community efforts (bridging capital) (Putnam, 2002; Kulig et al., 2008, 2013; Buikstra et al., 2010). Together these assets can help overcome perceived vulnerability and marginalization and contribute to the actual ability to take positive action (Satterfield et al., 2004).

Particularly relevant to this case are insights into the importance of social and cultural capitals that facilitate acceptance of change. Support for this argument has been quantified in the community psychology literature (e.g., Kulig, 2008; Norris, 2008), and are echoed in the findings of coal and mine closure transition research conducted internationally (Boutilier, 2017; Kinnear and Ogden, 2014; MorrisonSaunders et al., 2016), as well as other studies, focused on experiences with extractive industries (Haggerty et al., 2018). Most recently, Carley et al. (2018)'s study of eastern coal communities aligns with this theory, stating that their interviews demonstrate that "a primary component of ... [adaptation] is to embrace the move away from a culture of coal rooted in dependence to one focused on new opportunities..." (138).

The strong cultural affiliation that extractive industries can engender in host communities (termed variously "addiction" (Freudenburg, 1992) or "cognitive lock-in" (Hudson, 2005)) can limit the scope of transition planning. Affiliation with extractive industries operates as a foundation of the local moral economy (Smith and Tidwell, 2016) and as such can enhance bonding social capital. Indeed, deepening attachments to dwindling economies have been described as an explicit strategy to maintain and rationalize community stability in remote areas (McMillan Lequieu, 2017). These tendencies highlight the potential role for bridging capital in supporting efforts to expand community understandings of local economic futures.

To assess evidence of a positive, forward-looking outlook in economic transition plans, we focused on how each plan contextualized and approached the drivers of plant closure. In coding, we looked for language addressing and describing the need to develop economic alternatives and acknowledgment of the policy and market realities affecting coal's future. Strategies that promote policies to protect and maintain the coal industry as an economic development strategy were 
coded as the absence of acceptance of change.

\section{Methods}

This study applied a mixed-methods approach using direct qualitative content analyses (Creswell and Clark, 2011) to (1) identify power plants with recently retired or scheduled retirements and the counties where they are located; (2) inventory and categorize current planning efforts for the affected communities; and (3) conduct a qualitative content analysis assessing current planning efforts in relation to recommended strategies that have emerged from the literature.

\subsection{Data collection}

Data collection is described in Table 1 and involved both internet sources and personal communications with people familiar with specific coal facility processes. We secured 12 planning documents that address closures at 10 of the 18 power plants that have closed or will close in the U.S. West. (Exhaustive inquiries failed to produce planning documents for 6 of the facilities, suggesting planning has yet to be initiated or completed.) from each plan regarding its approach to each of the four criteria, and allowed us to generate a final, simplified coding scheme.

The final coding scheme (Table 3) served as an assessment guide for evaluating the extent that the plans address each of the four transition strategies. This assessment ranking helps provide a simple comparison of all of the plans. It complements, rather than replaces, a more detailed discussion of the variations across each criterion within the plans.

\section{Results}

Results of the assessment of plan content according to the four key transition planning criteria are shown in Table 4. This table shows that there is both a wide range of content in the plan database and in the types of strategies surfacing in planning for transition. The table suggests that some important criteria are missing altogether from some plans and that remediation as a local development opportunity has received attention from only two of 12 plans. It also shows that the importance of replacing lost revenue and of economic context is addressed in more than half the plans, but according to the coding, could use improvement. The discussion below provides more detail about each criterion.

Table 1

Data collection and preliminary assessment.

\begin{tabular}{|c|c|c|}
\hline Data & Criteria & Sources \\
\hline $\begin{array}{l}\text { Coal plant retirement } \\
\text { list }\end{array}$ & $\begin{array}{l}\text { - conventional thermal generating units categorized in the } \\
\text { electric power sector or as independent power producers } \\
\text { - combined generating threshold of } 75 \mathrm{MW} \text { for the plant. } \\
\text { - retired after } 2009 \text { or has a planned retirement date before } \\
2025\end{array}$ & $\begin{array}{l}\text { U.S. Energy Information Administration (EIA); Forms } 860 \text { and } 923 \text { Detail and } \\
\text { personal communications }\end{array}$ \\
\hline Transition plans & $\begin{array}{l}\text { - Plan specifically addresses the closure of one or more } \\
\text { generating units on list of retired/retiring facilities }\end{array}$ & $\begin{array}{l}\text { Personal communications with employees of power plant and associated coal } \\
\text { mines; city, county, and state government staff; NGO staff; Online documents }\end{array}$ \\
\hline
\end{tabular}

Upon collecting the transition plans, we observed a wide variety in content and approach. While each plan in the dataset addresses the closure of one or more generating units at one of the power plants, they varied in type and original intent. In order to better describe the dataset, we developed a simple typology shown in Table 2.

\subsection{Data analysis}

Qualitative content analysis methods were used to assess current planning efforts in relation to recommended strategies that emerged from the literature. This direct and deductive approach uses existing theory to guide a structured process of coding and identifying themes or patterns (Hsieh and Shannon, 2005). The dataset of planned or completed retirements described above served as the basis for qualitative content analysis. Prior to analysis, a "start list" of codes was established based on the transition strategies recommended in the economic development and community resilience literature (Miles and Huberman, 1994). The coding process was iterative and structured so that 2-3 independent researchers coded overlapping samples to test reliability and improve the coding scheme (Potter and Levin-Donnerstein,1999). This first stage produced a comprehensive comparative set of excerpts
Table 3

Assessment criteria.

\begin{tabular}{ll}
\hline Codes & Criteria \\
\hline 1 & content/quality is absent from plan \\
2 & content/quality is inaccurate \\
3 & content/quality is present, but incomplete \\
4 & content/quality effectively applies concepts from the literature
\end{tabular}

\subsection{How do plans address lost revenue?}

The plan database provides one striking observation about revenue loss: none of the local governments experiencing coal plant closures in places where coal plants act as keystones of the local property tax base had or have access to a dedicated transition fund at the outset of planning. Put another way, inadequate reserves were or are on hand locally to substitute for lost revenue in each of these six economies. As a result, each community relies on a political or negotiated process to secure replacement revenue.

Several plans effectively characterize the scale of revenue loss and

Table 2

Types of transition plans.

\begin{tabular}{|c|c|}
\hline Plan Type (Number in dataset) & Definition \\
\hline Economic Transition Plan (9) & $\begin{array}{l}\text { Developed specifically to address post-closure economic development and economic development plans that include discussions and } \\
\text { strategies associated with plant closures (most common are CEDS that were on going or initiated because of the closure). }\end{array}$ \\
\hline Decommissioning plans (1) & Address specific tasks associated with closure and remediation. \\
\hline Repowering Plans (1) & Address the reuse of the existing capacity at the plant. \\
\hline Impact Assessments (1) & Provide context and measure impacts directly related to closure but do not generate goals or strategies for transition. \\
\hline
\end{tabular}


Table 4

Number of plans at each assessment level for four key transition criteria.

\begin{tabular}{|c|c|c|c|c|c|}
\hline & & \multicolumn{4}{|l|}{ Criteria } \\
\hline \multicolumn{2}{|c|}{ Content Assessment } & Revenue & Remediation & Economic & Transition \\
\hline 1 & Absent & 3 & 7 & 5 & 0 \\
\hline 2 & $\begin{array}{l}\text { Problematic or } \\
\text { inaccurate }\end{array}$ & 2 & 3 & 0 & 4 \\
\hline 3 & $\begin{array}{l}\text { Present, but } \\
\text { incomplete }\end{array}$ & 3 & 0 & 4 & 4 \\
\hline 4 & $\begin{array}{l}\text { Adequately addresses } \\
\text { recommendations } \\
\text { from the literature }\end{array}$ & 4 & 2 & 3 & 4 \\
\hline
\end{tabular}

its potential negative impacts on communities. For example, among the plans associated with three major power plant facilities in the Southwest whose closure has profound implications for Native American communities, the strong dependency on coal revenues is well-documented (Ashley, 2016; Highland Economics, LLC and Catalyst Environmental Solutions, 2017; Hopi-EPA Clean Air Partnership, 2004; Sanzillo, 2017). The Navajo Generating Station is a large generating station in Page, Arizona on Navajo Nation land. Scheduled for 2019, the plant's closure has implications for both the Navajo and the Hopi nations which both receive revenues (and employment) at the plant and the associated coal mine. A plan written by independent consultants notes that "[c]oal revenues provide an estimated $80 \%$ of the Hopi tribe's budget and approximately $25 \%$ of funding for the Navajo Nation general fund, and have been declining over the past decade" (Sanzillo, 2017: 24). The plan goes on to suggest specific plans for revenue replacement based on the example of federal disbursements associated with military base closures, and also recommends investment from the State of Arizona's Utility Commission (Sanzillo, 2017: 25).

The suggested source of replacement revenue described above is just that, a suggestion. An example of a negotiated fund to compensate for lost revenue is the Memorandum of Agreement (MOA) established between the State of Washington and TransAlta Centralia Generation LLC in the case of the closure of the Centralia power plant in Washington state, planned to occur between 2020 and 2025. This agreement establishes three distinct funds-for weatherization, economic, and community development fund, and an energy technology investments-to receive a combined company contribution of $\$ 55,000,000$, beginning January 1, 2012 and ending December 31, 2023.

Where strategies are suggested to replace revenue with new growth or new energy development, the strategies are not well-developed. For example, there is little discussion about how the location of renewable energy facilities; specific state tax incentives and polices related to new industrial development; or state revenue and expenditure limitations will affect how revenue is generated by new activity. In many cases, replacing coal revenue with revenue from new growth would require changes to state or local fiscal policy. Discussions about how dependency on coal revenue occurred and if dependency can be reversed before plants retire to build transition reserves locally are largely unaddressed.

\subsection{Do plans include environmental restoration in economic development strategies?}

Across all the plans reviewed, restoration and remediation are underrepresented as economic development strategies. Less than half of the plans in our dataset refer to remediation or reclamation, and those that do focus on short-term employment opportunities could be more strategic. Specifically, most fail to integrate restoration work with place-based, long-term economic goals-which could involve the value of skills gained in restoration and/or the value of rehabilitated natural capital.

Among the five plans that feature discussions of remediation and reclamation of coal sites, the primary focus is on remediation and reclamation as a form of bridge employment and continued opportunities for local workers. In the most specific example, the plan developed to address the Argus Cogeneration Facility in Trona, California spelled out the labor requirements associated with remediation and describes a plan to use local labor for site clean-up. The plan suggests that clean up would offer about six additional months of work for the equivalent of 30 full-time employees (ACE Cogeneration Company [ACE], 2014: 5-6). Some but not all of the 30 would be from the existing workforce: "Long-term shut down activities will be performed by the existing ACE plant workforce. Demolition, removal, and final grading work will be performed by outside contractors with the appropriate expertise and licenses. The maximum demolition workforce including both ACE employees and demolition contractors is expected to be no more than 30 workers" (ACE, 2014: 4). The Four Corners Plan specifically addresses the local employment opportunities associated with coal mine restoration. The plan utilizes a SWOT analysis (Strengths, Weaknesses, Opportunities, and Threats) of mining reclamation that recognizes Northwest New Mexico "has a history of conducting mine reclamation using local firms [demonstrating] the region's ability to develop a local mine reclamation industry" (Highland Economics \& Catalyst Environmental Solutions, 2017: 104).

The plan written by the Institute for Energy Economics and Financial Analysis (IEEFA) for the Navajo Generating Station goes the furthest in recommending restoration extend beyond site remediation, asking for "comprehensive, inclusive environmental cleanup from damage to water, land and habitat caused by mining and coal plant activities over many years" (Sanzillo, 2017: 18). It also recommends a process using local stakeholder input and adequate resources for planning councils to bring in independent experts to assess environmental damages. However, beyond recommending that reclamation activities be done by displaced coal workers, even this plan does not link the outcomes of restoration to long-term economic development goals.

We also found in some plans a negative association between environmental regulations and growth. For example, one of the two plans written for Colstrip focuses on maintaining and expanding coal markets and attracting other large, single-industry employers recommends lowering environmental compliance costs as one strategy to incentivize capital investment (Taimerica et al., 2017). The Moffat County, Colorado CEDS similarly raises environmental issues primarily as a barrier, focusing on the opportunity costs associated with the need to manage for sensitive species like the Greater sage grouse or Yellow-billed cuckoo (Better City, 2015: 30).

\subsection{Are development strategies appropriate to local context?}

The majority of the plans address the opportunities and limitations available to them because of their relative connectivity to metropolitan areas, markets, or transportation infrastructure. However, many of the plans do not go beyond descriptive background towards viable solutions.

The plans written for the southwestern Navajo and Four Corners plants demonstrate awareness of associated weaknesses of rural regions; recognizing that the remote locations of the generating stations make commercial redevelopment of the industrial facilities unlikely. These plans properly focus on local strengths and opportunities. For example, the Four Corners plan emphasizes the importance of quality of life for local residents and points to an opportunity to promote the region's existing economic strength, through promotion of agri-tourism. The plan also highlights existing transmission infrastructure as a competitive advantage related to renewable energy development.

A plan organized by the regional economic development council for Colstrip also correctly focuses on comparative advantage. The plan identifies local assets associated with a high quality of life, access to 
outdoor recreation, and existing industrial capacity that could be repurposed and concerns about how remoteness from cities, health services, universities or training centers presents recruitment challenges. However, the strategies recommended in the plan do not reflect a full appreciation of the challenges facing a remote town of just over 2000 people with few or no connections to metropolitan areas.

Another problematic finding is that strategies focused on retaining or attracting a single large employer, often in a polluting industry, are over-represented. By comparison, we find too little consideration of the role of health care infrastructure, retirees, government institutions, non-labor income-often the largest and fastest growing sources of income and opportunity in many isolated communities.

One striking absence is any robust discussion of the opportunity costs associated with people versus place-based transition strategies. Funding and activities associated with workforce retraining, education assistance, and job relocation are designed to benefit individuals and their families. However, strategies intending to increase worker mobility can work against place-based efforts to stabilize communities. The lack of awareness of this tradeoff is demonstrated by the absence of discussion and planning for a shrinking population in remote locations, even among plans with well-developed workforce-related goals. The IEEFA and Trent Lott plans for the Navajo Generating Station and Colstrip included regional workforce assessments and recommended moving workers to jobs in the region but do not include discussions about how to plan for shrinking communities. Economic development strategies across all plans predominantly focus on diversifying and growing isolated communities after plant closures.

The specific economic and social vulnerabilities of indigenous nations with historic dependence on coal mining and coal facilities are spelled out in some planning documents and absent in others. Plans written for the Hopi and Navajo nations and the plan addressing the Four Corners plant closure do recognize the likelihood that coal facility closures will exacerbate some of the social and economic challenges that are endemic on reservations. However, the plans addressing Montana's Colstrip facility do not address the integration of the coal economy in the nearby Crow and Northern Cheyenne nations. This situation points to a risk that devolved, unstructured policy landscape for coal facility closure may reinforce existing social and political inequalities in some coal regions.

\subsection{Acceptance of change?}

All plans discussed the circumstances of transition in some way, but the twelve plans present a range of perspectives on the shifting circumstances of coal. Four plans demonstrated a strong positive outlook, willingness to change, and coherent grasp of greater policy and market circumstances. Four met these criteria to a lesser degree. Finally, four others were explicitly resistant to planning for a post-coal future.

Plans demonstrating failure to accept transition tended to blame closures on restrictive environmental regulations and ignore the role of markets, particularly price competition with natural gas and stagnant electricity demand. These plans focus on regulatory barriers instead of workforce and diversification strategies. For example, the Montana Coal Country Coalition plan prioritizes increasing coal exports via Pacific Coast Ports; modifying or eliminating the Clean Power Plan; developing clean-coal technologies; and lowering taxes and regulations to improve the state's business climate (Taimerica et al., 2017). These efforts, while in line with the current administration's political agenda, do not reflect the market realities surrounding coal.

Other plans show another outcome of the uncertainty associated with the dissonance between market trends and national energy and environmental policy: the tone of public discussion. This is evident in the Moffat County CEDs plan addressing the closure of Unit 1 of the Craig Generating Station. One-third less coal will be required after 2025, thereby reducing demand for coal in the nearby mining operations that supply the power plant. This plan does not recommend policies that support the status-quo, but it does provide some insight into the sentiments of the local community about the coal plant closure. The plan discusses a strong sense of "malaise" present during stakeholder interviews. The document's authors describe the uncertainty about the plant's future as a "cloud hanging over the county" (Better City, 2015: 28). The authors go on to note the potential for the sense of doom to act as an obstacle to growth and economic development in Moffat County. Recognition of local challenges is a key step in building the capacity to move through and beyond adversity (Buikstra et al., 2011).

By comparison, the Four Corners and Navajo nation plans both provide accurate summaries of the challenges facing the coal industry. Neither pin all the blame for coal's decline on environmental regulations, instead, the plans provide a breakdown of the market forces that are reducing the demand for coal and coal-fired electricity. The Four Corners plan goes into even greater depth on these market forces when examining the possibilities for the energy sector in northwest New Mexico, and more specifically the opportunities for coal in the region. The plan explains that the export of New Mexico coal is likely not feasible, due to lower mine costs in the PRB, high transportation costs, a lack of transportation infrastructure, and few export terminals capable of handling increases in coal exports (Highland Economics and Catalyst Environmental Solution, 2017: pg. 79). The plan does not make bold proclamations about leaving coal in the ground or immediately shutting these plants down, but is aware of the national trend away from coal and that northwest New Mexico needs to prepare for a future without coal. It is important to recognize that the Four Corners and IEEFA plans incorporate very low levels of community participation in plan development, calling to question the extent to which the community has accepted the transition.

\section{Discussion \& recommendations}

Two sets of observations follow from the findings of this survey of existing transition plan documents. First is a set of specific recommendations about steps and actions that can better enable planning processes to emulate those approaches to economic transition suggested by existing scholarship. The second set of observations involves the implications of the existing national and regional policy environment for transition planning and its outcomes.

\subsection{Recommendations: revenue}

The absence of structures to stabilize and replace revenue losses incurred with closure of industrial facilities is a major problem for local economies clearly documented in this dataset. Addressing these shortcomings could be accomplished by developing a transition revenue and investment (TRI) strategy that includes several components: local revenue strategies, state and federal assistance, and a spending strategy linked directly to economic development goals.

A primary goal of TRI strategies is to undo the dynamics that lead to dependence and exposure to fiscal crisis. In locations where the plants will continue to operate for some time, communities have an opportunity to build a local transition fund. If local levies are artificially low, local governments should be authorized to raise them to a statewide average and should set the additional revenue aside. A local transition fund could be financed by a local option severance, carbon, or generation tax, and paid for largely by out-of-state customers. In some cases, these options would require changes to state law to allow local governments to escape taxation and revenue limitations, and to establish dedicated, long-term savings funds. At the state and federal level, direct revenue sharing payments could be replaced with distributions from state endowments from coal extraction and coal-generation taxes and royalties. State governments use permanent endowments to stabilize revenue and earn income that generally funds annual state budgets. A portion of the income also could provide permanent and predictable 
funding for local transition fiscal plans.

TRI strategies also need to have a spending component that aligns budgets with strategic local investments identified as central to economic development and workforce goals (e.g., health services, schools, quality of life amenities, and/or infrastructure). Importantly, coal revenue and specific transition funds should not be used to fund annual operating budgets.

\subsection{Recommendations: environmental strategies}

We recommend communities re-imagine planning, funding and completing environmental remediation at and beyond the power plant site not as a burden, but as an opportunity. First, decommissioning and environmental restoration provide immediate employment opportunity for displaced workers. A TRI strategy could quantify the restoration needs and costs, including the labor requirements, and ensure revenue sufficient for these activities is available. Communities also could work with states and owners to ensure labor and income benefits are retained locally. Finally, as environmental amenities continue to play a prominent role in rural growth, it is imperative to integrate restoration and environmental outcomes and goals with long-term, economic development strategies.

\subsection{Recommendations: economic context}

Not surprisingly, this analysis of planning documents shows that communities tend to lack a clear vision of what post-coal economy looks like, and a corresponding strategic approach to integrating of fiscal, environmental, and community planning to achieve this vision. Investments in regional planning and expert input can help local plans maintain a critical distinction between investments in people and investments in places. Where investments in people make more sense, transition plans should also understand and have responses to the impacts associated with a declining population. We discuss the distinction between impact mitigation and long-term transition planning in the following section, and emphasize that this distinction must be clearly articulated and maintained by those conducting and supporting community planning.

\subsection{Recommendations: transition outlook}

An obvious paradox defines the situation facing coal-dependent communities: to be resilient, according to the literature, resource-dependent communities must accept and embrace change. However, according to the literature, to be resource-dependent, is to be predisposed toward support of industry (Freudenburg, 1992), a situation that expresses itself in the plans in our dataset that focus on assistance to the coal industry as a development strategy. These are likely to incur opportunity costs: early acceptance of a post-coal future allows more time and resources to employ proactive planning efforts.

Further research is needed to understand when and how planning processes can encourage and facilitate a positive outlook.

\subsection{Discussion: implications of current policy}

In the absence of a national policy framework that embraces the coal transition on the basis of environmental and market realities in the United States, the responsibility for planning for the impacts of the closure of coal-fired power plants and related facilities such as mines falls to local and state stakeholders. These stakeholders confront a complicated ownership, procedural and legal milieu in which the specific impacts of closure and the assignment of responsibility to mitigate closure impacts are determined on a case-by-case basis, including the interface of state and federal environmental legislation and state utility policy. Specific mandates regarding social and economic impacts from closure are minimal. This situation has several important, related implications for the economic plans and planning processes considered in this research.

First, in the current environment, local stakeholders must invest significant energy in assessing impacts and advocating for their mitigation. One obvious implication of this is the opportunity cost aspect: time spent procuring grants and advocating at regulatory and legislative hearings reduces time and energy for comprehensive local planning. In addition, local capacity and the expertise of entities selected to conduct impact assessments will strongly influence the quality and accuracy of the assessment. Our survey of transition plans demonstrates the variability that this 'do-it-yourself' scenario produces. More problematically, the logical extension of this observation is that local capacity may also be the ultimate determinant of success in advocacy for mitigating impacts. This implies that those communities with the least capacity are the least likely to negotiate truly strategic approaches to and support for impact assistance. This is an important area for future inquiry.

In addition, our analysis suggests that there are two linked domains in transition planning: one involving the immediate impacts to local livelihoods of contemporary residents of coal-dependent communities and another oriented toward the long-term viability of local livelihoods more generally. These domains most obviously manifest in the tradeoffs inherent to people versus place-based development strategies that exist at different scales (Goetz et al., 2017). We argue that current policy environment largely fails to recognize these distinctions. Further, the current policy environment not only underperforms on the former but worse, significantly neglects the latter. Local places may or may not successfully negotiate for immediate impact mitigation to address worker retraining or revenue replacement, but some processes suggest it is possible (e.g., Centralia's $\$ 55 \mathrm{~m}$ settlement).

However, successful long-term economic development planning is beyond the capacity of most local entities. It depends on a constellation of 'metagovernance' (Morrison et al., 2015) capacities and factors that our survey suggests are absent from the current planning space. First, there is an information shortfall. Long-term planning demands detailed regional economic assessments that include forward-looking economic scenarios informed by expert insights from state or federal agencies or economic professionals; creative strategies to curb ineffective revenue management depends on the sharing of ideas and suggestions across jurisdictions; full appreciation of the scope of potential benefits of full environmental remediation hinges on accurate accounting from other comparable projects. Second, incentives, opportunities, and mandates at the regional scale are lacking, encouraging a short-term, isolated approach to transition planning. Here is a clear role for a network of states to work together to share ideas, information, and advocate for transition policies that ensure equitable treatment for people and places affected by the coal transition.

\section{Conclusion}

In conclusion, in its consideration of the contours of the coal transition in the United States from the perspective of local planning responses to coal plant retirements, this study offers a blueprint for research and policy reform moving forward. Future research on transition planning conducted in diverse sites across the world must be executed and coordinated to enable discoveries of the circumstances that enable resilience, particularly in locations made vulnerable by demographic and geographic factors. In the meanwhile, federal and state governments in the United States, together with NGOs and other institutions face many challenges in reconciling the uncoordinated, contradictory policy environment to enable efficient and equitable approaches to supporting local economies during the coal transition.

\section{Acknowledgments}

The authors gratefully acknowledge the support of the U.S. National 
Science Foundation (Grant \#1632810) and the Just Transition Fund. We benefitted from constructive input from two anonymous reviewers, while all errors or omissions remain our own.

\section{Appendix A. Supporting information}

Supplementary data associated with this article can be found in the online version at http://dx.doi.org/10.1016/j.resourpol.2018.01.010.

\section{References}

ACE Cogeneration Company, 2014. Ace project decommissioning plan prepared for California Energy Commission. Retrieved from 〈http://docketpublic.energy.ca.gov/ PublicDocuments/86-AFC-01C/TN203376_20141125T154333_ACE_ Decommissioning Plan.pdf $>$.

Ashley, J., 2016. Hopi tribe comprehensive economic development strategy 2016 prepared for: Hopi Tribe Office of Community Planning and Economic Development. Retrieved from 〈http://www.hopi-nsn.gov/wp-content/uploads/2016/09/HopiComprehensive-Economic-Development-Strategy-Final-Draft-2016.pdf .

Aspen Institute, 2017. Rural-grown, local-owned manufacturing. America's Rural Opportunity Series. Washington, D.C. Retrieved from 〈https://www.aspeninstitute org/events/rural-manufacturing/>.

Beale, C., 2017. Rural America as a retirement destination. Aquaculture 3, 00.

BenDor, T., Lester, T.W., Livengood, A., Davis, A., Yonavjak, L., 2015. Estimating the size and impact of the ecological restoration economy. PloS One 10 (6), e0128339.

Besser, T.L., Recker, N., Agnitsch, K., 2008. The impact of economic shocks on quality of life and social capital in small towns. Rural Soc. 73, 580-604.

Better City, 2015. Moffat county comprehensive economic development strategy (CEDS) September 2016 to September 2021. Prepared for Moffat County. Retrieved from: 〈https://www.colorado.gov/pacific/sites/default/files/Moffat\%20County\%20CEDS. pdf $\rangle$.

Betz, M.R., Partridge, M.D., Farren, M., Lobao, L., 2015. Coal mining, economic development, and the natural resources curse. Energy Econ. 50, 893-896.

Boettner, T., Kriesky, J., McIlmoil, R., Paulhus, E., 2012. Creating an economic diversification trust fund: Turning nonrenewable natural resources into sustainable wealth for West Virginia. Retrieved from: 〈http://www.downstreamstrategies.com/ documents/reports_publication/ds_economic_diversification_trust_fund.pdf $\rangle$.

Boutilier, R.G., 2017. Raiding the honey pot: the resource curse and weak institutions at the project level. Extr. Ind. Soc. 4, 310-320.

Buikstra, E., Ross, H., King, C.A., Baker, P.G., Hegney, D., McLchlan, K., 2010. The components of resilience-perceptions of an Australian rural community. J. Commun. Psychol. 38 (8), 975-991.

Buikstra, E., Rogers-Clark, C., Ross, H., Hegney, D., King, C., Barker, P., McLachlan, K. 2011. Ego-resilience and psychological wellness in rural communities. In: Celinski, M., Gow, K.M. (Eds.), Continuity Versus Creative Response to Challenge: the Primacy of Resilience and Resourcefulness in Life and Therapy. Nova Press.

Carley, S., Evans, T.P., Konisky, D.M., 2018. Adaptation, culture, and the energy transition in American coal country. Energy Res. Soc. Sci. 37, 133-139.

Charnley, S., Donoghue, E.M., Stuart, C., Dillingham, C., Buttolph, L.P., Kay, W., Tobe, L. 2006. Northwest Forest Plan: the First 10 Years (1994-2003): socioeconomic monitoring results (USDA, Forest Service Publication No. PNW-GTR-649). Pacific Northwest Research Station, Portland.

Creswell, J., Clark, V., 2011. Designing and Conducting Mixed-methods Research. The Sage Handbook Of Qualitative Research, 2nd ed. SAGE Publications, Inc, Washington, D.C.

Deller, S.C., Tsai, T.H., Marcouiller, D.W., English, D.B.K., 2001. The role of amenities and quality of life in rural economic growth. Am. J. Agric. Econ. 83, 352-365.

Fan, Q., Goetz, S.J., Liang, J., 2016. The interactive effects of human capital and quality of life on economic growth. Appl. Econ. 48, 5186-5200.

Fleischman, L., Cleetus, R., Deyette, J., Clemmer, S., Frenkel, S., 2013. Ripe for retirement: an economic analysis of the U.S. coal fleet. Electr. J. 26, 51-63.

Freudenburg, W., 1992. Addictive economies: extractive industries and vulnerable localities in a changing world economy. Rural Sociol. 57, 305-332.

Gerking, S., Hamilton, S.F., 2008. What explains the increased utilization of Powder River Basin coal in electric power generation? Am. J. Agric. Econ. 90 (4), 933-950.

Goetz, S., Partridge, M., Stephens, H., 2017. The Economic Status of Rural America in the Trump Era. MPRA paper \#77830. Retrieved from: 〈https://mpra.ub.uni-muenchen. de/77830/1/MPRA_paper_77830.pdf $>$.

Grunwald, M., 2017. October 15). Trump's Love Affair with Coal: Why a president who struggles to stay on topic has a laser focus on one shrinking industry. Politico Magazine. Retrieved from 〈https://www.politico.com/magazine/story/2017/10/ 15/trumps-love-affair-with-coal-215710 $\rangle$.

Gunton, T., 2003. Natural resources and regional development: an assessment of dependency and Comparative advantage paradigms a staple theory of regional development. Econ. Geogr. 79, 67-94.

Haggerty, M.N., Haggerty, J.H., 2015. Energy development opportunities and challenges in the rural west. In: Danbom, D.B. (Ed.), Bridging the Distance: Common Issues of the Rural West. Sheridan Books, Inc., Ann Arbor, pp. 161-191.

Haggerty, J.H., Smith, K.K., Mastel, T., 2018. Assessing, monitoring, and mitigation energy boomtown impacts in the U.S.: evaluating a public health model. Impact Assess. Proj. Apprais. 36, 115-127.

Haggerty, J., Walsh, K.B., Haggerty, M., Rose, J., 2017. Colstrip: The Status of Key
Decision Processe. Retrieved from 〈http://www.montana.edu/energycommunities/ documents/Colstrip Status Report-FINAL.pdf〉.

Halseth, G., Ryser, L., 2006. Trends in service delivery: examples from rural and small town Canada, 1998 to 2005. J. Rural Community Dev. 1, 69-90.

Hayes, L.R., 1980. Energy, Economic Growth, and Regionalism in the West. University of New Mexico Press, Albuquerque.

Headwaters Economics, 2017a. Fragmented Ownership Complicates Power Plant Retirement for Affected Communities. Bozeman. Retrieved from: 〈https:// headwaterseconomics.org/energy/coal/communities-coal-plant-closures/>.

Headwaters Economics, 2017b. The changing role of manufacturing in the U.S. and insights for the rural west. Bozeman. Retrieved from $\langle$ https://headwaterseconomics. org/economic-development/trends-performance/changing-role-manufacturing/ $\rangle$.

Headwaters Economics, 2017c. The Transitions from Western Timber Dependence: Lessons for Counties. Retrieved from 〈https://headwaterseconomics.org/wpcontent/uploads/Lessons_Timber_Transition.pdf $\rangle$.

Hibbard, M., Lurie, S., 2013. The new natural resource economy: environment and economy in transitional rural communities. Soc. Nat. Resour. 26 (7), 827-844.

Higdon, J., 2017. The Obama Idea to Save Coal Country. Politico, Mar 8. 2017. Retrieved from 〈https://www.politico.com/magazine/story/2017/03/the-obamaadministration-idea-to-save-coal-country-214885〉.

Highland Economics, LLC \& Catalyst Environmental Solutions, 2017. Regional economic assessment \& strategy for the coal impacted four corners region prepared for Northwest New Mexico Council of Governments. Retrieved from 〈http://www. nwnmcog.com/uploads/1/2/8/7/12873976/final_highland_economics_report_2017. pdf $>$.

Hollander, J.B., Pallagast, K.M., Schwarz, T., Popper, F.J., 2009. Planning shrinking cities. In: Blanco, H. (Ed.), Shaken, Shrinking, Hot, Impoverished and Informal. Emerging research agendas in planning, pp. 195-250.

Hourser, T., Bordoff, J., Marsters, P., 2017. Can Coal Make a Comeback? Columbia Center on Global Energy Policy, New York.

Hopi-EPA Clean Air Partnership, 2004. The Hopi Tribe and the U.S. Environmental Protection Agency Clean Air Partnership Report. Retrieved from 〈https://energy. gov/sites/prod/files/2016/02/f30/hopi03final.pdf>.

Hsieh, H.F., Shannon, S.E., 2005. Three approaches to qualitative content analysis. Qual. Health Res. 15, 1277-1288.

Hudson, R., 2005. Rethinking change in old industrial regions: reflecting on the experiences of North East England. Environ. Plan. 37 (4), 581-596.

Istrate, E., 2014. Strong Economies, Resilient Counties: the Role of Counties in Economic Development. National Association of Counties, Washington, DC.

Joskow, P.L., 2000. Deregulating and regulatory reform in the US electric power sector

Kelly, E.C., Bliss, J.C., 2009. Healthy forests, healthy communities: an emerging paradigm for natural resource-dependent communities? Soc. Nat. Resour. 22 (6), 519-537.

Kinnear, S., Ogden, I., 2014. Planning the innovation agenda for sustainable development in resource regions: a central queensland case study. Resour. Policy 39, 42-53.

Kitson, M., Martin, R., Tyler, P., 2004. Regional competitiveness: an elusive yet key concept? Reg. Stud. 38 (9), 991-999.

Kulig, J.C., Edge, D.S., Joyce, B., 2008. Understanding community resiliency in rural communities through multimethod research. J. Rural Commu. Dev. 3 (3), 77-94.

Kulig, J.C., Edge, D.S., Townshend, I., Lightfoot, N., Reimer, W., 2013. Community resiliency: emerging theoretical insights. J. Community Psychol. 41, 758-775.

McMillan Lequieu, A., 2017. We made the choice to stick it out: negotiating a stable home in the rural. American Rust Belt, J. Rural Stud. 53, 202-213.

MacKinnon, D., Cumbers, A., Chapman, K., 2002. Learning, innovation and regiona development: a critical appraisal of recent debates. Prog. Hum. Geogr. 26 (3) 293-311.

MacLeod, G., 2001. New regionalism reconsidered: globalization and the remaking of political economic space. Int. J. Urban Reg. Res. 25 (4), 804-829.

Markey, S., Halseth, G., Manson, D., 2008. Challenging the inevitability of rural decline: advancing the policy of place in northern British Columbia. J. Rural Stud. 24 (4), 409-421.

McGranahan, D., 2008. Landscape influence on recent rural migration in the U.S. Landsc. Urban Plan. 85, 228-240.

Morrison-Saunders, A., McHenry, M., Sequeira, A., Gorey, P., Mtegha, H., Doepel, D., 2016. Integrating mine closure planning with environmental impact assessment: challenges and opportunities drawn from African and Australian practice. Impact Assess. Proj. Apprais. 34, 117-128.

Miles, M.B., Huberman, M.A., 1994. Qualitative Data Analysis: an Expanded Sourcebook, 2nd ed. Sage Publications, Inc, Thousand Oaks.

Morrison, T.H., Lane, M.H., Hibbard, M., 2015. Planning, governance and rural futures in Australia and the USA: revisiting the case for rural regional planning. J. Environ. Plan. Manag. 58, 1601-1616.

Neumark, D., Simpson, H., 2015. Place-Based Policies. In: Handbook of Regional and Urban Economics, 5, 1197-1287.

Newell, P., Mulvaney, D., 2013. The political economy of the 'just transition'. Geogr. J. 179, 132-140.

Norris, F.H., Stevens, S.P., Pfefferbaum, B., Wyche, K.F., Pfefferbaum, R.L., 2008. Community resilience as a metaphor, theory, set of capacities, and strategy for disaster readiness. Am. J. Community Psychol. 41, 758-775.

Potter, W.J., Levin-Donnerstein, D., 1999. Rethinking validity and reliability in content analysis. J. Appl. Commun. Res. 27, 258-284.

Putnam, R.D., Bowling Together. The American Prospect, 13, 20-22 2002.

Rabe, B., 2006. Race to the top: the expanding role of US state renewable portfolio standards. Sustain. Dev. Law Policy, 7, 10.

Raimi, D., 2017. Decommissioning U.S. Power Plants: Decisions, Costs, and Key Issues. Retrieved from 〈http://www.rff.org/research/publications/decommissioning-uspower-plants-decisions-costs-and-key-issues $\rangle$. 
Rasker, R., Gude, P.H., Gude, J.A., van den Noort, J., 2009. The economic importance of air travel in high-amenity rural areas. J. Rural Stud. 25, 343-353.

Renn, A.M., 2016. Should Economic Development Focus on People or Places? Governing. Retrieved from 〈http://www.governing.com/columns/eco-engines/gov-economicdevelopment-people-places.html $\rangle$.

Robertson, Daryl, 1979. Power plant and industrial fuel use of 1978: fuel replacement. Harv. Environ. Law Rev. 3, 214.

Rosenfeld, E., 2015. transition plans for coal-fired power plant closings: stability, opportunity, \& community. J. Energy Environ. Law 6, 71-82.

Ryser, L., Halseth, G., 2010. Rural economic development: a review of the literature from industrialized economies. Geogr. Compass 4 (6), 510-531.

Sanzillo, T., 2017. A transition plan for communities affected by the closings of Navajo Generating Station and Kayenta Mine. Retrieved from 〈http://ieefa.org/wp-content/ uploads/2017/06/IEEFA-Transition-Plan-for-Navajo-Generating-Station-andKayenta-Mine-060617.pdf $>$.

Satterfield, T.A., Mertz, C.K., Slovic, P., 2004. Discrimination, vulnerability, and justice in the face of risk. Risk Anal. 24, 115-129.

Smith, M.D., Krannich, R.S., Hunter, L.M., 2001. Growth, decline, stability, and disruption: a longitudinal analysis of social well-being in four western rural communities. Rural Sociol. 66 (3), 425-450.

Smith, J.M., Tidwell, A.S.D., 2016. The everyday lives of energy transitions: contested sociotechnical imaginaries in the American West. Social Studies of Science 46 (3), 327-350.

Stephens, H., Partridge, M., Faggian, A., 2013. Innovation entrepreneurship and economic growth in lagging regions. J. Reg. Sci. 53, 778-812.

Sullivan, L., Ryser, L., Halseth, G., 2014. Recognizing change, recognizing rural: the new rural economy and towards a new model of rural service. J. Rural Community Dev. 9 (4), 219-245.

Taylor, B., Hufford, M., Bilbrey, K., 2016. A green new deal for Appalachia: economic transition, coal reclamation costs, bottom-up policymaking (Part 1). J. Appalach. Stud. 23, 8-29.

Taimerica Management, Competitive Solutions, \& Trent Lott National Center, 2017. The changing coal industry: regional economic impacts-workforce analysis-transition strategies prepared for the Montana Coal Country Coalition. Retrieved from $\langle$ http:// www.bigskyeconomicdevelopment.org/wp-content/uploads/Coal-Country-
Coalition-Report-FINAL-3-17.pdf $>$.

Tollefson, J., 2017. How Trump plans to wipe out Obama-era climate rules. Nat. News. 〈https://www.nature.com/news/how-trump-plans-to-wipe-out-obama-era-climaterules-1.21726〉.

U.S. Energy Information Administration, 2014. AEO2014 projects more coal-fired power plant retirements by 2016 than have been scheduled. Retrieved from $\langle$ https://www. eia.gov/todayinenergy/detail.php?Id = 15031>.

U.S. Energy Information Administration, 2016. Average utilization for natural gas combined-cycle plants exceeded coal plants in 2015. Retrieved from 〈https://www.eia. gov/todayinenergy/detail.php?Id $=25652>$.

U.S. Energy Information Administration, 2017a. Electric Power Annual. [Form EIA-860 detailed data]. Retrieved from 〈https://www.eia.gov/electricity/data/eia860/〉.

U.S. Energy Information Administration, 2017b. Quarterly Coal Report. Retrieved from $\langle$ https://www.eia.gov/coal/production/quarterly/〉.

U.S. Environmental Protection Agency, 2016. EPA announces mercury and air toxics standards (MATS) for power plants - rules and fact sheets. Washington, D.C. Retreived from 〈https://www.epa.gov/mats/epa-announces-mercury-and-air-toxicsstandards-mats-power-plants-rules-and-fact-sheets $>$.

Vaneeckhaute, L.E., Vanwing, T., Wolfgang,, Jaquet, Abelshausen, B., Meurs, P., 2017. Community resilience 2.0: toward a comprehensive conception of community-level resilience. Community Dev. 1-17.

Whitener, L., 2005. Policy options for a changing rural America. Retrieved from 〈http:// www.ers.usda.gov/amber-waves/2005/april/policy-options-for-a-changing-ruralamerica〉.

Wilkinson, C.F., 1999. Fire on the Plateau: Conflict and Endurance in the American Southwest, 2nd ed. Island Press, Washington, D.C.

Winkler, R., Field, D., Luloff, A., Krannich, R., Williams, T., 2007. Social Landscapes Of The Inter-mountain west: a comparison of 'old west' and 'new west' communities. Rural Sociol. 72, 478-501.

Woods, Michael, 2005. Rural Geography: processes, Responses and Experiences in Rural Restructuring. SAGE Publications Inc, Thousand Oaks.

United States Dept of Energy (DOE), 2017. Staff Report to the Secretary on Electricity Markets. Retrieved from: 〈https://energy.gov/downloads/download-staff-reportsecretary-electricity-markets-and-reliability $\rangle$. 